LEDinko, N. (1956). J. gen. Microbiol. 15, 47-60

\title{
An Analysis of the Process of Adaptation of Influenza Virus B of Recent Human Origin to the Mouse Lung
}

\author{
BY NADA LEDINKO* \\ The Walter and Eliza Hall Institute of Medical Research, \\ Melbourne, Australia
}

SUMMARY: During the course of adaptation to the mouse lung of the Rob strain of influenza $B$, 'pure' clones of virus were isolated from bronchial washings at succeeding passages by the limiting infective dilution technique in chick embryos. The clones were studied for various in vitro and in vivo properties. A progressive dominance was obtained in the virus population of virus particles causing extensive pulmonary consolidation. Those particles which produced extensive consolidation became resistant to inhibition of heated virus haemagglutinin by sheep mucin. A complete correlation was found between the appearance of resistance to sheep mucin inhibitor and a decrease of enzymic activity on sheep mucin.

From the heterogeneous population of particles found in the early course of mouse passage a virus was isolated which exhibited all of the tested properties of the adapted virus. In comparison to a non-pathogenic virus form, these properties included: (a) the production of extensive pulmonary consolidation, high mortality of mice, and multiplication of virus on serial mouse passage; $(b)$ the production of a more rapid growth rate, and the ability to multiply to a greater extent; $(c)$ the inability of heated virus haemagglutinin to be inhibited by sheep mucin and ovomucin; $(d)$ a decrease of enzymic activity on sheep mucin and mouse lung inhibitors under certain experimental conditions; and (e) a high position in the fowl red cell receptor gradient.

The above data offer presumptive evidence that one of the processes operative in the adaptation process of Rob virus to the mouse lung is a selection of mutants found in the unadapted heterogeneous virus population.

Studies dealing with the adaptation of influenza viruses to the mouse lung have revealed that a number of properties may differentiate mouse-adapted from unadapted strains. These properties include differences in multiplication characteristics in mice (Wang, 1948; Davenport \& Francis, 1951; Briody \& Cassel, 1955) and eggs (Ginsberg, 1953), in reactivity to the $\beta$ inhibitor (Davenport, 1952; Briody, Cassel \& Medill, 1955), and in other in vitro characteristics such as heat stability (Burnet, 1951 $a$; Ledinko, 1955), inhibition of indicator virus haemagglutination by mucoids (Ledinko, 1955), and position in the receptor gradient (Burnet, 1951 $a$; Ledinko, 1955). These findings indicate that changes in the virus population may play an important part during the course of adaptation.

By studying the distribution of mouse lung pathogenicity among 'pure' clone samples of the CAM strain of influenza A prime virus at various stages of adaptation, Burnet \& Lind (1954) concluded that the results obtained supported the hypothesis of a successive replacement of one population by another

* Present address: The Children's Hospital of Philadelphia, 1740 Bainbridge Street, Philadelphia 46, Pennsylvania, U.S.A. 
more suited for survival. This would agree with the findings of Davenport (1954) that not all virus particles in an unadapted virus population possess an equal potential to adapt to the mouse lung. Briody \& Cassel (1955) and Briody et al. (1955) have obtained evidence which indicates that the process of adaptation is accompanied by a series of interrelated changes in the virus population.

In a previous study with the Rob strain of influenza $B$ virus (Ledinko, 1955 ) it was found that mouse-adapted Rob virus differed from its unadapted parent in a number of in vitro as well as in vivo characteristics. Therefore a study was undertaken of various in vitro as well as in vivo properties of 'pure' clones of Rob virus, isolated by the limiting infective dilution technique in chick embryos at succeeding mouse passages, in an attempt to elucidate some of the characteristics of the survival advantage and consequent adaptation to the mouse lung of this virus.

\section{METHODS}

Virus. The Rob strain of influenza $B$ virus was used. This strain had received eleven limit infective dilution passages allantoically in 11-day embryonated eggs since its initial isolation in the amnion. The complete history has been described (Ledinko \& Perry, 1955). A $\mathrm{CO}_{2}$ ice cabinet was used for storage of all virus preparations.

Limit infective dilution (LD) technique. All LD isolations refer to fluids obtained from an inoculum of the test material which did not infect more than $40 \%$ of 11-day embryonated eggs, using 15-20 eggs per inoculum. The eggs were inoculated allantoically, and allantoic fluids harvested after 3 days' incubation.

Haemagglutinin $(H A)$ titrations. To $0.25 \mathrm{ml}$. of each two-fold serial dilution of the test material, $\mathbf{0} .25 \mathrm{ml}$. of a $1 \%$ suspension of fowl erythrocytes was added. The tests were read as soon as the cells in the control tubes had settled at room temperature. The end-point was taken as the + degree of partial agglutination. The titre is expressed as the reciprocal of the dilution at the end-point. The dilution at the end-point contains one fowl agglutinating dose of virus (FAD).

Infectivity titrations. Tenfold serial dilutions of the test material were inoculated allantoically into groups of 10 to 12 -day chick embryos. $0.05 \mathrm{ml}$. of each dilution was inoculated into six eggs. After incubation for $\mathbf{7 2} \mathrm{hr}$. at $\mathbf{3 5}^{\circ}$, the eggs were tested for HA. On this basis, the $50 \%$ egg infectivity end point $\left(\mathrm{EID}_{50}\right)$ was calculated according to Reed \& Muench.

Inoculation of mice. $0.05 \mathrm{ml}$. of the test material diluted to 1 FAD was inoculated intranasally under light chloroform-ether anaesthesia into groups of 4- to 5-week old mice. For virus passage, lungs were removed from six mice 2 to 3 days after inoculation, and bronchial washings were collected according to a technique described by Fazekas de St Groth (1948), and used previously with Rob virus (Ledinko \& Perry, 1955). The individual washings were pooled, diluted to 1 FAD, and inoculated into mice, usually on the same day. 
To determine the mouse pathogenicity score, using six mice per group, mice still alive 7 days after inoculation were killed and examined for lung lesions. The method of scoring lung lesions was as follows:

$5 \cdot 0$ Complete consolidation, death of mouse on 4th or 5th day.

4.0 Complete consolidation, death of mouse on 6 th or 7 th day.

3.0 More than half of lung consolidated.

2.0 Approximately half the visible area of the lung surface consolidated.

1.0 About 1/6 to $1 / 4$ of lung surface consolidated.

$0.5,0.2$, and trace for smaller areas of damage.

Inhibitors. Sheep salivary gland mucin was prepared from submandibular glands according to McCrea (1951). The titres refer to a stock solution containing $1 \%$ (dry wt.) in normal saline.

Cyst mucin purified from the contents of an ovarian cyst by the method of McCrea (1949) was used. The stock solution contained $1 \%$ of dried material in normal saline.

Ovomucin was prepared as described by Gottschalk \& Lind (1949). The titres refer to a stock solution containing $0.2 \%$ (dry wt.) in normal saline.

Meconium was prepared according to the technique described by Curtain, French \& Pye (1953). The titres refer to a stock solution containing $1 \%$ (dry wt.) in normal saline.

Mouse lung suspension was prepared from 4-week old mice. Lungs were removed from twelve normal mice, ground with alundum, and suspended in normal saline ( $1 \mathrm{ml}$./lung). The suspension was lightly centrifuged, the supernatant fluid removed and stored at $4^{\circ}$.

Bronchial washings were collected from twelve normal mice by the technique of Fazekas de St Groth (1948). The washings were pooled and stored at $4^{\circ}$.

Production of indicator virus. Virus was diluted with 1 vol. of citrate-borate saline ( $10 \%$ by volume of standard borate buffer at $\mathrm{pH} 8.5$ and $0.2 \%$ sodium citrate in normal saline) and heated at $56^{\circ}$ for $30 \mathrm{~min}$. (Stone, 1949).

Titration of inhibitor-sensitivity of virus. See Stone (1949). Serial two-fold dilutions of inhibitor were prepared in $\mathbf{0 . 2 5} \mathrm{ml}$. normal saline. An equal volume of a dilution of indicator virus containing 5 FAD was added to each tube. After an incubation of $30 \mathrm{~min}$. at room temperature, $\mathbf{0 . 2 5} \mathrm{ml}$. of a $1 \%$ suspension of red cells was added. The test was read by the pattern of $\mathbf{H A}$ after a further hour at room temperature. The titre is expressed as the reciprocal of the dilution of the inhibitor at the end point of partial agglutination.

Titration of inhibitor-destroying activity of virus. See Stone (1949). Serial two-fold dilutions of virus were prepared in $\mathbf{0 . 2 5} \mathrm{ml}$. volumes of calciumacetate saline, and to each was added $0.25 \mathrm{ml}$. of a standard dilution of inhibitor (containing five to ten inhibitory doses, each dose being capable of inhibiting $5 \mathrm{FAD}$ of the indicator virus used). After incubation for $1 \mathrm{hr}$. at $37^{\circ}$ the mixtures were heated at $65^{\circ}$ for $30 \mathrm{~min}$. to destroy the virus haemagglutinin, then cooled to room temperature. One drop of appropriate indicator virus containing 5 FAD was added to each tube, and after $80 \mathrm{~min}$. at room temperature $0.25 \mathrm{ml}$. of a $1 \%$ suspension of fowl cells. The test was read by the pattern of $\mathbf{H A}$ after a further hour at room temperature. The 
inhibitor-destroying (ID) titre is expressed as the reciprocal of the dilution of virus at the end-point of partial agglutination.

Position in the receptor gradient. The method used was described by Isaacs \& Edney (1950). Semi-purified receptor-destroying enzyme (RDE) of Vibrio cholerae prepared according to the method of Ada \& French (1950) was used. Fowl cells were treated for $30 \mathrm{~min}$. at $37^{\circ}$ with graded dilutions of RDE and subsequently washed with citrate saline. To $\mathbf{0 . 2 5} \mathrm{ml}$. of a $1 \%$ suspension of treated cells, $0.25 \mathrm{ml}$. of $5 \mathrm{FAD}$ of virus was added. The titre is read as the reciprocal of the dilution of $\mathrm{RDE}$ which results in cells agglutinated to a + level of partial agglutination.

\section{EXPERIMENTAL,}

Mouse lung pathogenicity of LD fluids isolated at each succeeding mouse passage. The course of adaptation to the mouse lung of Rob virus, using 1 FAD as the inoculum at each passage, is shown in Fig. 1. Inoculation of the virus resulted in the production of extensive pulmonary consolidation, followed by a decrease in consolidation with continued passage, and a subsequent gradual rise in pulmonary lesions. This biphasic course is similar to that obtained using Rob virus which had undergone three LD allantoic passages, as

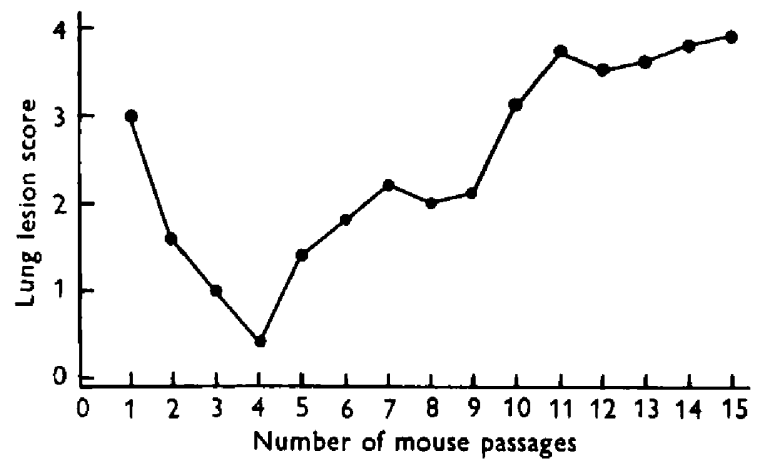

Fig. 1. Mouse lung pathogenicity scores obtained with Rob virus on serial mouse passage.

described previously (Ledinko \& Perry, 1955). It was considered then that the first phase might be the result of virus particles whose properties were related to the previous (natural) human passage, since continued passage in the chick embryo resulted in a gradually diminishing ability of the virus to produce consolidation of the mouse lung in the early course of mouse passage. Therefore, in the present study, the course of 'true' adaptation will be considered to begin with the 4th mouse passage. Beginning with this passage, at which minimal lung lesions were seen, a gradual increase in the extent of pulmonary consolidation was observed. Mortality and extensive pulmonary consolidation were obtained by the 11 th passage and were transferable through a number of additional passages.

The LD fluids isolated in eggs from the bronchial washings obtained at each mouse passage were tested for mouse lung pathogenicity. Only fluids which 
were subsequently shown to be 'pure' after an additional limit dilution passage (as indicated by the sheep mucin inhibitor-sensitivity property described in the next section) are included in the data. One FAD of each fluid was inoculated. As may be seen in Table 1, a progressive change was noted in the virus population leading to a progressive dominance of those virus particles which produced extensive pulmonary consolidation. Similar results were obtained by Burnet \& Lind (1954) using the CAM strain of influenza A prime virus.

Table 1. Mouse lung pathogenicity of $L D$ fluids isolated at each mouse passage

\begin{tabular}{|c|c|c|c|c|c|c|c|}
\hline \multirow{3}{*}{$\begin{array}{c}\text { Mouse } \\
\text { passage } \\
\text { no. }\end{array}$} & \multirow{3}{*}{$\begin{array}{c}\text { Average } \\
\text { lesion } \\
\text { score }\end{array}$} & \multirow{3}{*}{$\begin{array}{l}\text { No. of } \\
\text { LD fluids }\end{array}$} & \multicolumn{5}{|c|}{$\begin{array}{l}\text { No. of fluids. Pathogenicity score } \\
\text { (inoculum I FAD) }\end{array}$} \\
\hline & & & 0 & $0.1-0.9$ & $\begin{array}{c}\begin{array}{c}1 \cdot 0-1 \cdot 9 \\
\text { Class }\end{array} \\
.\end{array}$ & $2 \cdot 0-2 \cdot \theta$ & $3.0-$ \\
\hline & & & 0 & I & II & III & IV \\
\hline 2 & $1 \cdot 6$ & 6 & 0 & 2 & 4 & 0 & 0 \\
\hline 3 & 1.0 & 12 & 0 & 1 & 8 & 8 & 0 \\
\hline 4 & 0.4 & 10 & 0 & 6 & 2 & 2 & 0 \\
\hline 5 & 1.4 & 10 & 0 & 1 & $\mathbf{3}$ & 4 & $2^{*}$ \\
\hline 6 & 1.8 & 17 & 0 & $\mathbf{8}$ & $\mathbf{B}$ & $7\left(5^{*}\right)$ & 4* \\
\hline 7 & $2 \cdot 2$ & 12 & 0 & 0 & 1 & $3\left(1^{*}\right)$ & $8^{*}$ \\
\hline 8 & 2.0 & 17 & 0 & 0 & 0 & $1 *$ & $16^{*}$ \\
\hline 9 & $2 \cdot 1$ & 13 & 0 & o & 0 & 0 & $13^{*}$ \\
\hline 11 & $8 \cdot 7$ & 4 & 0 & 0 & 0 & 0 & $4^{*}$ \\
\hline 15 & 3.9 & 5 & 0 & 0 & 0 & 0 & $5^{*}$ \\
\hline
\end{tabular}

Sheep mucin inhibitor-sensitivity titrations of $L D$ fluids isolated at each mouse passage. In a previous study (Ledinko, 1955) of the differential characteristics between mouse-unadapted Rob virus and its mouse-adapted derivative, it was found that one of the differentiating properties was the conversion of unadapted virus to the indicator phase, by heating at $56^{\circ}$ for $80 \mathrm{~min}$., as tested with sheep mucin inhibitor. The adapted virus was not converted; i.e. no inhibition of indicator virus haemagglutination by sheep mucin occurred. It was similarly found in the present study that the adapted virus could not be converted to the indicator phase even after heating with citrate-borate buffer at pH 8.5 (Stone, 1949). Therefore, the LD fluids isolated at each mouse passage were tested for their ability to be inhibited after heating by sheep mucin inhibitor. Those LD fluids which could not be converted into indicators are marked with an asterisk in Table 1, while the sheep mucin inhibitor-sensitivity titres of the fluids are given in Table 2.

It can be seen that the ability to be converted to the indicator state was lost concomitantly with a rise in pulmonary consolidation during mouse passage, as indicated by the average lesion score. Furthermore, only those fluids which produce extensive pulmonary consolidation lost the indicator property. In Table 2, in contrast to the gradual changes in virulence of the virus population, a sharp differentiation in inhibitor titres is seen. This may be an indication of a single-step mutational change in contrast to the multiple-step change shown 
to exist for mouse lung virulence (Burnet, 1954). In a similar study by Briody et al. (1955), using strains of type $A$ prime and type $B$ influenza viruses, the appearance of extensive pulmonary consolidation was correlated with the sudden loss of susceptibility by unheated virus to both $\mathrm{HA}$-inhibition and to neutralization by $B$ inhibitor in normal ox serum. In the present study the haemagglutination by active unadapted and adapted virus was not inhibited by sheep mucin.

\section{Table 2. Sheep mucin inhibitor sensitivity titrations of $L D$ fluids}

\begin{tabular}{|c|c|c|c|}
\hline $\begin{array}{c}\text { Mouse } \\
\text { passage } \\
\text { no. }\end{array}$ & $\begin{array}{l}\text { Average } \\
\text { lesion } \\
\text { score }\end{array}$ & $\begin{array}{l}\text { No. of } \\
\text { LD fluids }\end{array}$ & $\begin{array}{c}\begin{array}{c}\text { Sheep mucin inhi- } \\
\text { bitor sensitivity test }\end{array} \\
\begin{array}{l}\text { Range of log of } \\
\text { inhibitor titre* }\end{array}\end{array}$ \\
\hline $\mathbf{2}$ & $1 \cdot 6$ & 6 & $\mathbf{3} \cdot 8-\mathbf{3} \cdot \mathbf{9}$ \\
\hline $\mathbf{3}$ & $1 \cdot 0$ & 12 & $3 \cdot 8-4 \cdot 0$ \\
\hline 4 & 0.4 & 10 & $3 \cdot 8-3 \cdot 9$ \\
\hline 5 & $1 \cdot 4$ & 10 & $3 \cdot 8-4 \cdot 0(8) ;<1-1 \cdot 1(2) \dagger$ \\
\hline 6 & 1.8 & 17 & $3.9-4.0(8) ;<1-1.1(8)$ \\
\hline $\boldsymbol{7}$ & $2 \cdot 2$ & 12 & $3 \cdot 9-4 \cdot 0(8) ;<1-1 \cdot 2(\theta)$ \\
\hline 8 & $\mathbf{2 \cdot 0}$ & 17 & $<1-1.2$ \\
\hline 9 & $\mathbf{2 \cdot 1}$ & 18 & $<1-1 \cdot 1$ \\
\hline 11 & $3 \cdot 7$ & 4 & $<1-1-2$ \\
\hline 15 & $\mathbf{8 \cdot \boldsymbol { 9 }}$ & 5 & $<1-1 \cdot 2$ \\
\hline
\end{tabular}

* Increasing the time of contact between inhibitor and indicator virus before adding red cells to $3 \mathrm{hr}$. incubation did not alter the titre obtained.

$\dagger$ Number in parentheses represents number of LD fluids showing the titre indicated.

The sheep mucin inhibitor-destroying activity of $L D$ fluids isolated at each mouse passage. The inhibitor-destroying activity of virus has been used as a measure of its enzymic activity (Stone, 1949). The titration of this characteristic gives an estimate of the dilution of virus capable of destroying a standard dose of inhibitor under specified conditions. The sheep mucin inhibitordestroying activity of the 'pure' clones of virus isolated at various mouse passage levels is shown in Table 3 . The activity is expressed in terms of a ratio of the inhibitor-destroying titre to the haemagglutinin titre. The results indicate that complete enzymic destruction of sheep mucin inhibitor occurred in the early passages (ratio 0.5-1.0), while no destruction of the inhibitor occurred in the later passages (ratio $<0.01$ ), under the experimental conditions used. There is a complete correlation between the marked loss of the indicator property and decrease of enzymic activity of the LD fluids tested.

Separation of components from mixed virus population. The experimental results in the preceding sections revealed that a heterogeneous collection of viruses was present in the bronchial washings of the early mouse passages, both in regard to pathogenicity and indicator property. An inspection of the data in Table 1 indicated that at least four different virus components were found with the following differential characteristics: (1) non-pathogenic, indicator, NP-I (5); (2) pathogenic, indicator, P-I (5); (3) pathogenic, non-indicator from an early passage, $\mathrm{P}-\mathrm{NI}$ (5); and (4) pathogenic, non-indicator from a late passage P-NI (15). Viruses of types $1-3$ were selected from the 5th mouse 
passage, and of type 4 from the 15th passage, and carried through five to six additional egg LD passages. The properties of these separated presumably 'pure' viruses are shown in Table 4. These properties remained constant through the LD passages.

Table 3. Sheep mucin inhibitor-destroying activity of $L D$ fluids

\begin{tabular}{|c|c|c|}
\hline $\begin{array}{c}\text { Mouse } \\
\text { passage } \\
\text { no. }\end{array}$ & $\begin{array}{l}\text { No. of } \\
\text { LD fluids }\end{array}$ & $\begin{array}{c}\begin{array}{c}\text { Sheep mucin inhi- } \\
\text { bitor-destroying test }\end{array} \\
\begin{array}{c}\text { Range of ID } \\
\text { titre/HA titre* }\end{array}\end{array}$ \\
\hline $\mathbf{2}$ & 6 & $0 \cdot 5-1 \cdot 0$ \\
\hline 3 & 12 & $0.5-1.0$ \\
\hline 4 & 10 & $0.5-1.0$ \\
\hline 5 & 10 & $0.5-1.0(8) ;<0.01(2)$ \\
\hline 6 & 17 & $0.5-1.0(8) ;<0.01(9)$ \\
\hline 7 & 12 & $0.5-1.0(3) ;<0.01(9)$ \\
\hline 8 & 17 & $<0.01$ \\
\hline 9 & 13 & $<0.01$ \\
\hline 11 & 4 & $<0.01$ \\
\hline 15 & $\mathbf{5}$ & $<0.01 \dagger$ \\
\hline
\end{tabular}

* ID titre is reciprocal of dilution of virus capable of destroying the inhibitor for indicator NP-I (see next section) in a standard dose of sheep mucin.

$\dagger$ To determine whether longer incubation would enable the adapted virus to act on the sheep mucin inhibitor, incubation was prolonged for $18 \mathrm{hr}$. at $37^{\circ}$. Some destruction of the inhibitor did occur (ID/HA = approx. 0*1).

Table 4. Differential characteristics of separated viruses

\begin{tabular}{lccc}
\multicolumn{1}{c}{ Type } & $\begin{array}{c}\text { No. of } \\
\text { LD passages }\end{array}$ & $\begin{array}{c}\text { Mouse } \\
\text { lesion } \\
\text { score }\end{array}$ & $\begin{array}{c}\text { Log of sheep } \\
\text { mucin inhibitor } \\
\text { sensitivity titre }\end{array}$ \\
NP-I (5)* & 5 & 0.1 & $\mathbf{3 . 9}$ \\
P-I (5) & 6 & $2 \cdot 8$ & 3.8 \\
P-NI (5) & 6 & 3.7 & $<1.0$ \\
P-NI (15) & 5 & 3.9 & $<1.0$
\end{tabular}

$\mathbf{N P}=$ non-pathogenic, $\mathbf{P}=$ pathogenic, $\mathbf{I}=$ indicator, $\mathrm{NI}=$ non-indicator.

* Number in parentheses indicates the mouse passage from which fluid was isolated.

Determination of specificity of inhibitor effect. The inter-relationship of the development of extensive pulmonary consolidation with the loss of conversion to the indicator state as tested with sheep mucin inhibitor was noted previously. This prompted the testing of other inhibitors in inhibitor-sensitivity tests using the following viruses: NP-I (5), P-NI (5) and P-NI (15). The inhibitors tested with the three heated viruses were: sheep mucin, mouse lung, cyst mucin, ovomucin, meconium and bronchial washings. The results are shown in Table 5. It was found that heated NP-I (5) virus was inhibited by all of the inhibitors tested. Little or no effect on heated P-NI (5) and P-NI (15) viruses was shown by ovomucin and sheep mucin inhibitors only. The other inhibitors tested inhibited both the P-NI (5) and P-NI (15) viruses.

In view of the findings of Davenport (1952) that haemagglutination by unadapted influenza virus was inhibited by the inhibitor in normal mouse lung 
to a greater degree than was observed with the adapted virus, it might be expected that the above inhibitor-sensitivity tests using the mouse lung inhibitor would also reveal a marked difference between NP-I (5) and P-NI (15) viruses. However, the lung extract would not only contain the cellular receptors concerned in the course of infection. A further experiment was done in order to determine whether a differential effect of the two viruses could be detected in the enzymic test. The mouse lung inhibitor-destroying activity of NP-I (5), P-NI (5) and P-NI (15) viruses was therefore tested. The inhibitordestroying titre was obtained using three different indicator viruses, as noted in Table 6. Stone (1949) had shown that the type of indicator virus markedly influenced the titre obtained with some strains. As seen in Table 6, NP-I (5)

Table 5. Determination of specificity of inhibitor effect

\begin{tabular}{ccccccc} 
Heated & \multicolumn{7}{c}{ Log of inhibitor sensitivity titre } \\
virus & $\begin{array}{c}\text { Sheep } \\
\text { mucin }\end{array}$ & $\begin{array}{c}\text { Mouse } \\
\text { lung }\end{array}$ & $\begin{array}{c}\text { Cyst } \\
\text { mucin }\end{array}$ & Ovomucin & Meconium & $\begin{array}{c}\text { Bronchial } \\
\text { washings }\end{array}$ \\
NP-I (5) & $\mathbf{3 . 9}$ & $\mathbf{3 . 0}$ & $\mathbf{3 . 8}$ & 3.1 & 3.5 & 1.7 \\
P-NI (5) & $<1.0$ & $\mathbf{2 . 6}$ & $\mathbf{3 . 7}$ & 1.2 & 3.4 & 1.7 \\
P-NI (15) & $<1.0$ & $\mathbf{2 . 5}$ & $\mathbf{8 . 5}$ & $<1.0$ & 3.5 & 1.6
\end{tabular}

Table 6. Mouse lung inhibitor-destroying titrations

\begin{tabular}{lccc} 
& \multicolumn{3}{c}{$\begin{array}{c}\text { Mouse lung inhibitor-destroying test. } \\
\text { ID titre/HA titre }\end{array}$} \\
\cline { 2 - 4 } Virus & Indicator & Indicator & Indicator \\
NP-I (5) & P-NI (15) & P-NI (5) \\
P-NI (5) & 0.6 & 0.7 & 0.6 \\
P-NI (15) & $<0.01$ & 0.6 & 0.8 \\
& $<0.01$ & 0.5 & 0.9
\end{tabular}

virus completely destroyed the mouse lung inhibitor. P-NI (5) and P-NI (15) viruses were found to be fully active against the mouse lung inhibitor for their own indicators. No activity was manifest by $\mathrm{P}-\mathrm{NI}$ (5) and $\mathrm{P}-\mathrm{NI}$ (15) viruses when NP-I (5) virus was used as the indicator virus. Fazekas de St Groth (1950) has shown that the inhibitor of bronchial washings for heated Lee virus is destroyed during influenza virus infection.

Receptor gradient position of $N P-I(5), P-N I(5)$ and $P-N I$ (15) viruses. The experimental results shown in the preceding sections revealed that $\mathrm{P}-\mathrm{NI}$ (5) and $\mathbf{P}-\mathrm{NI}$ (15) viruses showed the same reactivity with a number of inhibitors (Tables 5 and 6 ), as well as the capacity to produce extensive pulmonary consolidation (Table 4). The position of NP-I (5), P-NI (5), and P-NI (15) viruses in the receptor gradient using fowl red cells treated with graded amounts of RDE was next examined. The NP-I (5) virus was found to occupy a low position in the gradient, with a titre of 16, while P-NI (5) and P-NI (15) viruses occupied a much higher position in the gradient, both viruses having a titre of 128 . 
Mouse lung passage of $P-N I$ (5) and $P-N I$ (15) viruses using bronchial washings. The adapted P-NI (15) virus produces extensive pulmonary consolidation, mortality of mice, and multiplication of virus as determined by $\mathrm{HA}$ and egg infectivity titres of the bronchial washings on serial mouse passage. The behaviour of $\mathrm{P}-\mathrm{NI}$ (5) virus under similar experimental conditions was compared to that of P-NI (15) virus. One FAD of $42 \mathrm{hr}$. LD allantoic fluid preparations was inoculated. Bronchial washings collected 2 days after virus inoculation were used as the source of virus, and $1 F A D$ was used as the inoculum at each passage. The results are shown in Table 7. From these and the above data it appears that P-NI (5) virus originally isolated from bronchial washings of the 5th mouse passage possesses all the properties, tested so far, of the fully adapted virus, exemplified by P-NI (15).

Table 7. Bronchial wash passages of $P-N I$ (5) and $P-N I$ (15) viruses

\begin{tabular}{|c|c|c|c|c|c|c|c|c|c|}
\hline \multirow{3}{*}{$\begin{array}{c}\text { Virus } \\
\text { inoculum }\end{array}$} & \multirow{2}{*}{\multicolumn{3}{|c|}{$\begin{array}{l}\text { Test for virus } \\
\text { HA titre of BW } \\
\text { of passage no. }\end{array}$}} & \multicolumn{6}{|c|}{ Pathogenicity } \\
\hline & & & & \multicolumn{3}{|c|}{$\begin{array}{l}\text { Lung lesion score } \\
\text { passage no. }\end{array}$} & \multicolumn{3}{|c|}{$\begin{array}{c}\text { Percentage } \\
\text { mortality }\end{array}$} \\
\hline & 1 & 2 & $\mathbf{3}$ & 1 & 2 & 3 & 1 & $\mathbf{2}$ & $\mathbf{3}$ \\
\hline P-NI (5) & 18 & 22 & 30 & $\mathbf{3} \cdot 5$ & $3 \cdot 6$ & $\mathbf{3} \cdot \mathbf{5}$ & 50 & 60 & 60 \\
\hline P-NI (15) & 35 & 36 & 32 & $\mathbf{3 \cdot \theta}$ & $3 \cdot 8$ & $\mathbf{8 \cdot 9}$ & 80 & 60 & 80 \\
\hline
\end{tabular}

Further experiments provided direct support of the findings of Davenport (1954) that an influenza virus population has an unequal capacity for adaptation. Eight mouse lung passages of NP-I (5) and P-I (5) viruses, using bronchial washings as described above, were carried out. No change was noted in any of the in vitro and in vivo properties of these viruses as shown in Table 4. The lesion score of P-I (5) remained a value of approximately 2.8 at each mouse passage. This substrain therefore showed no capacity to mutate to the P-NI type in the above short series.

Growth curves of $N P-I(5), P-I(5), P-N I$ (5) and $P-N I$ (15) viruses. In their studies on the adaptation of influenza virus to mice, Briody \& Cassel (1955) have shown that concomitantly with the ability to produce extensive pulmonary consolidation there is acquired the ability by an influenza type $\mathbf{A}$ prime strain to grow at an accelerated rate. In order to define further the properties characterizing the selective advantage of $\mathrm{P}-\mathrm{NI}$ (15) virus, the multiplication pattern of NP-I (5), P-I (5), P-NI (5) and P-NI (15) viruses was compared.

One FAD of $42 \mathrm{hr}$. LD allantoic fluid preparations of the four viruses was inoculated intranasally into groups of mice. Four mice from each group were killed at 2 hr., 1, 2, 8 and 4 days after inoculation. Mouse lung suspensions were prepared. Egg infectivity titrations were performed with each suspension. Representative results of three experiments are given in Fig. 2. A difference greater than a $0 \cdot 6 \log$ unit between the $\mathrm{EID}_{60}$ titres of two samples was taken as being significant. 
The data depicted in Fig. 2 indicate that, in comparison to NP-I (5) virus, P-I (5), P-NI (5), and P-NI (15) viruses exhibit the ability to multiply to a greater extent, as well as to produce an accelerated growth curve. In contrast to P-I (5), the fully adapted virus possesses a differential reactivity with inhibitors.

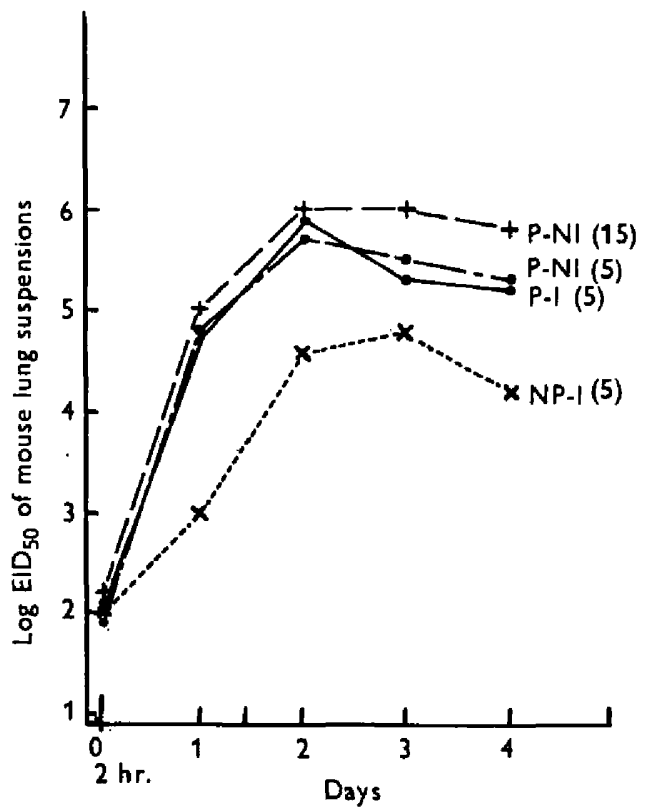

Fig. 2. Egg infectivity titrations of mouse lung suspensions at various intervals after mouse inoculation with NP-I (5), P-I (5), P-NI (5) and P-NI (15) viruses.

\section{DISCUSSION}

The results of experiments attempting to elucidate some of the characteristics of the process of adaptation to the mouse lung of Rob virus have shown that the virus form at the end of the process differs from an unadapted form in: $(a)$ a high and stable virulence; $(b)$ the ability to produce an accelerated growth curve and to multiply to a greater extent; $(c)$ the inability to be converted to the indicator phase as tested with sheep mucin and ovomucin inhibitors; $(d)$ a marked decrease of enzymic activity on sheep mucin and mouse lung inhibitors; and $(e)$ a shift to a high position in the fowl red cell receptor gradient.

The complexities of the interaction of active and indicator influenza viruses with mucoid macromolecules and the red cell surface have been extensively summarized by Burnet $(1951 b)$. The simplest hypothesis to account for the above in vitro properties ( $c, d$ and $e$ ) would be that adaptation to the mouse lung of Rob virus is associated with two characteristics. The preferential combination of the heated adapted virus with the red cell rather than with the inhibitor in the inhibitor sensitivity three-component test (Anderson, Burnet, Fazekas de St Groth, McCrea \& Stone, 1948) indicates a change in the affinity 
of adsorption to sheep mucin and ovomucin inhibitors resulting in decreased inhibitor reactivity. The inhibitor-destroying tests and altered reactivity with fowl cells treated with RDE point to a masking, or a loss, of at least some of the enzyme groups on the virus surface. There is indicated, therefore, a change in the spatial arrangement of the adsorptive and enzymically active groups on the virus surface.

As suggested from the experimental data, these adsorptive and enzymic changes may be the result of a single-step mutational change acquired by the virus particle along with the ability to produce extensive lung lesions. The question arises whether these changes represent functionally important changes in the adaptation process or whether they are 'accidentally' associated changes to those involving virulence. The growth curve studies using the different viruses isolated from the fifth and fifteenth passages may provide some evidence on this point. The results of these experiments revealed that P-I (5) virus, i.e. a virus possessing pathogenicity and indicator properties, and P-NI (15) virus, i.e. a virus which was pathogenic and a non-indicator, grew at an accelerated rate and multiplied to a greater extent than NP-I (5) virus, a nonpathogenic virus with the indicator property. Therefore, the ability of the virus to grow at an accelerated rate and to multiply to a greater extent is correlated only with the ability to produce extensive lung lesion production, and not necessarily with the adsorptive and enzymic changes noted. However, since in these experiments adaptation resulted in the selection of a virus of the type P-NI, an additional selective advantage of such a virus presumably exists. The adsorptive and enzymic changes noted above may, accordingly, be a reflexion of the mutation of a virus particle to a decreased reactivity with the inhibitor, or inhibitors, present in the lung tissue during the course of infection. Such a particle would then make a more rapid contact with the susceptible cells than a non-mutated one. This may be, in turn, correlated with a shortened lag phase in the growth cycle. Growth curve determinations at intervals of less than $24 \mathrm{hr}$. should provide evidence for this point. On the other hand, other unknown mutations of the virus particle may be important determinants of the selective survival advantage of P-NI type virus.

In the $\mathrm{O}-\mathrm{D}$ transformation of influenza virus (Stone, 1951), the two phases exhibit a differential behaviour against soluble inhibitors. Multiplication in the amniotic cavity of the chick embryo gave rise to mutants which differed in their agglutination of fowl red cells, weakly at first, and in being able to multiply in the allantoic cavity. O-phase virus was enzymically active against human ovarian cyst mucin but not against ovomucin of chick embryo lung. D-phase virus acted on all three inhibitors. After transformation to the indicator state, $O$ virus was inhibited only by the human mucin, while $D$ virus was inhibited both by human and avian mucins. These changes of the adsorptive-enzymic properties of the $\mathrm{O}-\mathrm{D}$ transformation are plausibly explained as having evolved in relation to the multiplication of the virus in the chick embryo. The changes of the adsorptive-enzymic mechanism in the present study did not follow a similar pattern. It was seen that after transformation to the indicator state both the unadapted and adapted Rob viruses were 
inhibited by bronchial washings and mouse lung preparations. Furthermore, under certain experimental conditions, adapted virus showed a reduced enzymic activity against the mouse lung inhibitor, while unadapted virus was enzymically active. In elaboration of the discussion in the previous paragraph, it may be that the changes in the adsorptive-enzymic mechanism found above are related to a decreased reactivity with intracellular mucoid receptors. The possibility of intracellular receptors playing a part in infection has been raised by Edney \& Isaacs (1950).

According to Burnet (1956) there is a gradual change of the virus in the chick embryo from $O$ to $D$, and not a simple replacement of $O$ virus by an increasing proportion of $\mathrm{D}$ virus particles. At least two intermediates have been postulated. The present findings indicate that at least two 'intermediates' are present in bronchial washings collected from an early stage of adaptation. In contrast to the fully adapted virus which could not be converted to the indicator state as tested with sheep mucin inhibitor, two viruses were isolated: (a) a virus which was non-pathogenic and could be converted to the indicator state; and $(b)$ a virus which was pathogenic, but not to the extent shown by the fully adapted virus, and which also could be converted into an indicator.

In addition to these two viruses, a virus possessing all of the tested properties of the fully adapted virus was isolated from the bronchial washings collected from an early stage of adaptation. This provides some experimental evidence in support of previous hypotheses stating that adaptation results from the selection of mutants, whether occurring during mouse passage, or present in the original inoculum, or both. However, that other processes may also operate in the adaptation process is indicated from an inspection of the course of adaptation in Fig. 1, where only a gradual rise in pathogenicity of the virus population is evident. If adaptation consisted merely of a selection of a particular mutant, a more rapid acquisition of extensive lung pathogenicity might be expected. In line with the hypothesis of Davenport (1954), one can envisage a more dynamic state, resulting in the development of many mutant forms of virus. Further mutations of various intermediate forms might take place, and interference and competition of these for the susceptible cells would occur. Genetic interaction between various virus forms might also be expected to occur, as is indicated by the experiments of Burnet \& Lind (1954). While it would appear that mutations are the primary factors in mouse lung adaptation, a Lamarckian change may also operate.

A diversity of behaviour in the study of mouse adaptation has been encountered by various investigators. Hirst (1947) has shown that the enhancement of virulence with mouse passage of an influenza $A$ virus is not due to an increasing ability of the agent to grow in the lung. In their studies using an influenza A prime strain, Burnet \& Lind (1954) have observed a variable delay in the appearance of any lesion-producing capacity and, once this capacity has appeared, a rapid increase to maximal activity occurs. Adaptation is envisaged as a steplike process with many inheritable grades. It appears probable that different mechanisms operate for different viruses in regard to virus population changes in the adaptation process. 
It seems likely, however, that adaptation of influenza virus to the mouse lung may conform to the broad meaning indicated by Stanier (1953) in relation to adaptation among micro-organisms. The totality of processes enabling a heterogeneous virus population to multiply in a new environment would include both genetic and environmental factors, including the selection of a virus better fitted to adapt to the new surroundings.

The author is a Fellow of the National Foundation for Infantile Paralysis. She is indebted to Professor Sir Macfarlane Burnet, F.R.S., for his advice and criticism.

\section{ADDENDUM}

After this manuscript was completed, a paper was published with data relevant to the above work (Medill-Brown, M. \& Briody, B. A., 1955, Mutation and selection pressure during adaptation of influenza virus to mice, Virology, 1, 301). The authors conclude that the process primarily taking place during mouse lung adaptation of an influenza $B$ strain is a selection of mutants resistant to $\mathrm{B}$-inhibitor.

\section{REFERENCES}

Ada, G. L. \& French, E. L. (1950). Purification of the receptor destroying enzyme of $V$. cholerae. Aust. J, Sci. 13, 82.

Anderson, S. G., Burnet, F. M., Fazekas, S., McCrea, J. F. \& Stone, J. D. (1948). Mucins and mucoids in relation to influenza virus action. VI. General discussion. Aust. J. exp. Biol. med. Sci. 26, 403.

Briody, B. A. \& Cassel, W. A. (1955). Adaptation of influenza virus to mice. II. Changes in the growth curve of an $\mathbf{A}$ prime strain of influenza virus. J. Immunol. 74, 37.

Briody, B. A., Cassel, W. A. \& Medill, M. A. (1955). Adaptation of influenza virus to mice. III. Development of resistance to $\beta$ inhibitor. J. Immunol. 74, 41 .

BURner, F. M. (1951 $a$ ). A genetic approach to variation in influenza viruses. 1. The characters of three substrains of influenza virus A (WS). J. gen. Microbiol. 5, 46.

Burnet, F. M. (1951 b). Mucoproteins in relation to virus action. Physiol. Rev. 31, 131.

BurNet, F. M. (1954). Virulence in animal viruses. Lancet, ii, 559.

Bunnet, F. M. (1956). Enzyme, Antigen and Virus: a Study of Macromolecular Pattern in Action. (In the Press.) Cambridge University Press.

Burnet, F. M. \& Lind, P. E. (1954). An analysis of the adaptation of an influenza virus to produce lesions in the mouse lung. Aust. J. exp. Biol. med. Sci. 32, 711.

Curtain, C. C., French, E. L. \& Pye, J. (1953). The preparation and properties of an inhibitor of influenza virus haemagglutination from human meconium. Aust. J. exp. Biol. med. Sci. $31,349$.

Davenport, F. M. (1952). Adaptation of influenza virus to mouse lungs. Fed. Proc. 11,465 .

Davenport, F. M. (1954). 'The inequality of potential in influenza virus for adaptation to mice. J. Immunol. $\mathbf{7 2 ,} 485$.

Davenport, F. M. \& Francis, T. (1951). A comparison of the growth curves of adapted and unadapted lines of influenza virus. J. exp. Med. 93, 129.

Edney, M. \& IsaAcs, A. (1950). Interference between inactive and active influenza viruses in the chick embryo. III. Inhibitor of virus haemagglutination in the chorio-allantoic membrane. Aust. J. exp. Biol. med. Sci. 28, 603. 
Fazekas de St Groth, S. (1948). Destruction of influenza virus receptors in the mouse lung by an enzyme from $V$. cholerae. Aust. J. exp. Biol. med. Sci. $26,29$.

Fazekas de St Groth, S. (1950). Studies in experimental immunology of influenza $I$. The state of virus receptors and inhibitors in the respiratory tract. Aust. J. exp. Biol. med. Sci. 28, 15.

GinsBerg, H. S. (1958). Comparison of quantity of egg and mouse-adapted influenza viruses required to infect each host. Proc. Soc. exp. Biol., N.Y. 84, 249.

Gotrschalk, A. \& Lind, P. E. (1949). Ovomucin, a substrate for the enzyme of influenza virus. I. Ovomucin as an inhibitor of haemagglutination by heated Lee virus. Brit. J. exp. Path. 30, 85.

Hinst, G. K. (1947). Studies on the mechanism of adaptation of influenza virus to mice. J. exp. Med. 86, 857 .

IsAACs, A. \& EDNEy, M. (1950). Variation in laboratory stocks of influenza viruses: Biological characters of variants. Brit. J. exp. Path. 31, 196.

Ledinko, N. (1955). Studies with influenza virus $B$ of recent human origin. II. Genetic interaction with Mil strain of influenza B virus. $J$. Immunol. 74, 880 .

Ledinko, N. \& Perry, B. (1955). Studies with influenza virus B of recent human origin. I. Adaptation to the mouse lung. J. Immunol. 74, 371.

MCCREA, J. F. (1949). Biochemical aspects of the virus haemagglutination phenomenon, and the related immunological and serological problem. Ph.D. Thesis, University of Melbourne.

MoCrea, J. F. (1951). A mucoid from sheep submandibular glands inhibiting haemagglutination by influenza virus. Biochem. J. 48, xlix.

Stanier, R. Y. (1958). Adaptation, evolutionary and physiological: or Darwinism among the micro-organisms. Adaptation in micro-organisms. Symp. Soc. gen. Microbiol. 3, 1.

STone, J. D. (1949). Inhibition of influenza virus haemagglutination by mucoids. I. Conversion of virus to indicator for inhibitor. Aust. J. exp. Biol. med. Sci. 27, 837.

Stone, J. D. (1951). Adsorptive and enzymic behaviour of influenza virus during the O-D change. Brit. J. exp. Path. 32, 367.

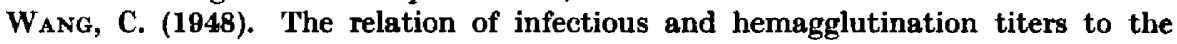
adaptation of influenza virus to mice. $J$, exp. Med. 88, 515 .

(Received 12 December 1955) 